AUTHOR:

J. L. van der Walt

AFFILIATION:

Edu-HRight Research Focus Area,

Faculty of Education Sciences,

Potchefstroom Campus, North-West

University, South Africa

CORRESPONDENCE TO:

J. L. van der Walt

EMAIL:

hannesv290@gmail.com

POSTAL ADDRESS:

Private Bag X6001, Potchefstroom

Campus, North-West University,

Potchefstroom, 2520, South Africa

DATES:

Published: 03 Mar. 2017

HOW TO CITE THIS ARTICLE:

van der Walt, J.L., 2017,

'Neoliberalism and education: A

reformational-pedagogical perspective

(part 1)', Koers - Bulletin for Christian

Scholarship 82(1), Available at https://

doi.org/10.19108/KOERS.82.1.2275

COPYRIGHT:

(c) 2017. The Author(s).

Published under the Creative

Commons Attribution License.

\section{Neoliberalism and education: A reformational-pedagogical perspective (part 1)}

\begin{abstract}
This article forms yet another link in a series of studies and publications from the pens (computers) of South African reformational educationists regarding the so-called-isms deemed to be threats to the Christian (Biblical) orientation to education (including teaching and learning). In this, the first part of the article, a brief overview is given of how these reformational educationists have so far responded to the various "-isms" that they perceived to be threats or challenges to Christian education. This is followed by an attempt to define the concept "neoliberalism" and to indicate what it means in general, and in particular, in the educational context. This part of the article paves the way for a critical analysis of neoliberalism as

a "philosophy of education" and of its transcendental preconditions in the second part.
\end{abstract}

Key concepts: liberalism, neoliberalism, education, Christian education, teaching and learning, philosophical preconditions, transcendental foundations

\section{Opsomming}

Die neoliberalisme en opvoeding en onderwys:'n reformatories-pedagogiese perspektief (deel 1)

Hierdie artikel is 'n verdere skakel in 'n reeks studies en publikasies uit die penne (rekenaars) van Suid-Afrikaanse reformatoriese opvoedkundiges wat verband hou met die sogenaamde -ismes wat hulle beskou het as bedreiginge vir die Christelike (Bybelse) siening oor opvoeding (insluitend onderwys in die sin van onderrig en leer). In hierdie deel van die artikel word eerstens' $n$ kort oorsig gegee oor hoe die reformatoriese opvoedkundiges tot dusver te werk gegaan het om die "-ismes" wat hulle beskou het as bedreigings vir, of as uitdagings aan die Christelike opvoeding en onderwys, aan die kaak te stel. Dit word gevolg deur'n poging om die begrip "neoliberalisme" te omskryf en te stel wat dit breedweg impliseer, veral in 'n opvoedkundige konteks. Hierdie deel van die artikel berei die weg voor vir' $n$ kritiese ontleding van neoliberalisme as ' $n$ "opvoedingsfilosofie" en van sy transendentale voorwaardes in die tweede deel van die artikel.

Kernbegrippe: liberalisme, neoliberalisme, opvoeding, onderwys, Christelike opvoeding en onderwys, onderrig en leer, filosofiese uitgangspunte, transendentale grondslae

\section{Introduction and background}

South African reformational philosophers of education have always tended to respond critically to philosophies (of education) that they regarded not only as alien to the Christian way of thinking about the human being and education but indeed also as a threat to the Christian pedagogical orientation. One of the first responses to such a "threat" by a South African reformational philosopher of education was the contribution by J Chris Coetzee in a critical study of pragmatism. He entitled the book Die moderne opvoeding: 'n Histories-kritiese studie (Modern Education: A Historical-critical study) (1939)'. In 1964, C F G Gunter published a book entitled Opvoedingsfilosofieë: Op weg na 'n Christelike

Since these publications are only referred to here for historical background purposes, and have not been consulted for the purpose of the argument unfolding hereafter, their bibliographical particulars are not reflected in the bibliography. 
Opvoedingsfilosofie (Philosophies of Education: Developing a Christian Philosophy of Education) in which he critically engaged with Naturalism, Idealism, Pragmatism, Existentialism and Phenomenology from a Christian perspective. Around the same time (undated), B C Schutte published a study entitled Die objektivistiese en die fenomenologiese benaderings in die empiriese opvoedkunde (The objectivistic and phenomenological approaches in Empirical Education).

His successor as Professor in Philosophy of Education at the former Potchefstroom University for Christian Education, J H van Wijk, continued the work mentioned above by doing studies on Idealism, Naturalism, Pragmatism, Socialism, Communism, Existentialism, Phenomenology and the New Left. These studies were subsequently collated and published by $\mathrm{J} L$ van der Walt in a book entitled Strominge in die Opvoedingsteorie (Trends in the Theory of Education) (1979). Van Wijk's successors in Philosophy of Education at the same university, J L van der Walt and W Postma, published a sequel to this book (Strominge in die Opvoedingsteorie 2, 1987), in which they engaged with the New Right, the New Humanism, Alternative Schooling, Indigenous African Education, Communism in Africa, Islam, Buddhism and Zen-Buddhism. Around this time, S G Roos, a Christian in his private life but an exponent of South African phenomenology in his academic capacity, published a book entitled Geestelike Weerbaarheid teen Ideologiese Terrorisme (Spiritual Preparedness against Ideological Terrorism)(1979).

As the publication of books became less of a financially viable proposition in South Africa after 1990, authors began concentrating on publishing scholarly articles on philosophical and theoretical trends that they regarded as potentially threatening to reformational education. Towards the end of his life, Pieter G Schoeman, Emeritus Professor of Philosophy of Education at the University of the Free State, wrote a series of articles on the subjects of ideology, belief systems, morality, fundamentalism and relativism (several of them published in the Journal of Christian Scholarship)(2003-2011). Around the same time, Van der Walt and Fowler (2004) published an article on chaos and education. This formed part of a series of articles by Van der Walt in which he dealt with several of the so-called -isms: Linguistic analysis (1981); Neo-Marxism (1989); Postmodernism (1989); Multicultural Education (1995); Constructivism (co-edited by A de Muynck, 2006); Ubuntu (2010) and Post-postfoundationalism (2014), to mention only a few².

This article on neoliberalism and education forms yet another link in this chain of articles in connection with philosophical trends that might be regarded as threats to the reformational orientation to education.

\section{Neoliberalism: What is it?}

There are two obstacles to overcome when attempting to describe what neoliberalism is as such or what it entails. The first is that it has no definite proponents whose publications one could consult (Boas \& Gans-Morse, 2009: $\mathrm{npn}^{3}$ ). Most of the available circumscriptions of neoliberalism come from the pens or computers of its critics and hence tend to be negative and occasionally even caustically critical of neoliberalism. The second is that it is not quite clear what the term "neoliberalism" encapsulates, as the following brief overview of literature on the subject reveals.

2 Reformational philosophers in general also see this as one of their duties. Dutch philosopher $\mathrm{H}$ Dooyeweerd (c. 1923), for instance, dealt critically with both Idealism and Realism in one of his very first academic publications. South African philosopher E A Venter discusses Modern Humanism and Existentialism in his book Wysgerige Temas (Philosophical Themes)(1970). D F M Strauss similarly dealt with several "-isms" in his book Philosophy: Discipline of the Disciplines (2009). 
Shenk (2015: npn) rightly refers to the term "neoliberalism" as a "loose and shifting signifier". According to Rustin (2016:153) and Sparkes (2007: 528), the term appears to name an ideology. Adams (2006:7) also refers to neoliberalism as not only an ideology but also as a faith or a belief. Rustin (2016: 154) refers to it as a "pervasive influence". Palley (2004: npn) and Boas and Gans-Morse (2009, npn), in turn, see it as a philosophy, whereas Jones, Parker and Ten Bos (2005: 100) regard it as "a set of ideas". Marois and Pradello (2015: 1, 2) see it as a policy but also as a "historical phenomenon". Shenk $(2015, \mathrm{npn})$ and the economist Wendy Brown whom he interviews use even vaguer concepts in referring to it: "a governing rationality," "a form of political reason", "a governing form of reason". Adams (2006: 78) refers to it as "a paradigm shift", a "form of rationality" and even as a "principle" and as a "belief". In Welch's (1998:157, 170) opinion, it is a "form of economic rationality" and / or "a functionalist theory". Hall $(2011: 10,18)$ is inclined to see it as a "model", and Maistry (2014:59) as "a theoretical framework".

Neoliberalism, then, as Rustin (2016:153) has concluded, although it appears to name an ideology, is a term also used to refer to the entire post-1980 capitalist system which it dominates. As will be demonstrated below, it has many variants (Hall, 2011:12).

In view of this terminological confusion, Hall (2011:10) seems to be correct in concluding that the term "neoliberalism" is not a satisfactory one. As will be demonstrated below, it lumps together a wide variety of circumstances and conditions and hence does not refer to a single entity. In the process, it sacrifices attention to internal complexities and geohistorical specificity.

Despite the haziness of the term, however, one could aver that neoliberalism comes down to a Zeitgeist that has somehow infiltrated current thinking about education, and is therefore worthwhile examining from a reformational pedagogical perspective.

\section{Neoliberalism: Its origins and history}

Historically, neoliberal ideas are rooted in the principles of "classic" liberal economic and political theory, as propounded by, among others, Jeremy Bentham and John Stuart Mill. Liberalism in its "classical" form pivoted on the notion of the human being as free, free to profit from the rise of the commercial-consumer society of the $1800 \mathrm{~s}$. It emphasised the rights of free men, the right to accumulate wealth, and to pursue one's own interests. "Classic" liberalism availed itself of the full lexicon of bourgeois ideas: possessive individualism, freedom, equality, ownership of private property, self-interest, a limited form of state, free trade and the right to accumulate capital (Hall, 2011: 13; Palley, 2004: npn). In a sense, neoliberalism or contemporary liberalism now dreams of restoring all these classic liberal ideas.

Classic liberal ideas as such began to lose their impetus by the late 19th century but neoliberalism, which rose from the 1970s, "came to its rescue" by borrowing and appropriating extensively from its classic predecessor. Neoliberalism differs from classic liberalism in that it adds a further and explicit market inflexion to the classic liberal ideas. Classic liberal precepts are now being radically transformed to make them more applicable to a modern (20th-21st century) global, post-industrial information-age form of capitalism.

As mentioned before, it is difficult to find exponents and proponents of neoliberalism. It might have had its roots in the ideas of the Freiburg School of Economics (in Germany) in the 1930s (Boas \& Gans-Morse, 2009: npn). The School's main argument was that only some forms of competition are good while others might require oversight (by the state). The School provided the theoretical elements of ordo liberalism ${ }^{4}$ and of the social market economy in 
post-war Germany. According to Boas and Gans-Morse (2009: npn), the members of the School saw their philosophy as more moderate in comparison with classic liberalism, both in its rejection of laissez-faire policies and its emphasis on humanist values.

Neoliberalism as a contemporary form of liberalism is principally associated with the ideas advanced by the Chicago School of Economics: emphasis on the efficiency of market competition, the role of individuals in determining economic outcomes, distortions associated with government intervention and the regulation of markets (in which this School differs from the German ordo liberals)(Palley, 2004: npn).

Neoliberalism as a widespread view or philosophy of life and the world caught on from the mid to late 1970s in the form of the economic policies introduced by Margaret Thatcher in the United Kingdom and Ronald Reagan in the United States of America following their elections respectively in 1979 and 1981 (Jones, Parker \& Ten Bos, 2005:100). In the early 1970s, firms began to feel acutely the impact of falling productivity. Many managers and owners of businesses believed that the mounting power of organised labour was responsible for this. At the same time they experienced the challenges associated with the rising socialism and nationalism from the Global South. The power of the United States of America also reached its nadir with its defeat in Vietnam (1975), with the Iranian Revolution in the late 1970s, and with the spread of revolutionary struggles, notably in Latin America. The gradual relinquishing of Keynesianism which held sway in the Western world between 1945 and 1980 can be ascribed to the impact of the Vietnam War but also to the OPEC oil price shocks which dominated the 1970s. The Cold War furthermore popularised an economic rhetoric that spoke of "natural free markets" independent of government domination and in which government regulation was believed to lead to a reduction of human well-being. The idea began to take root that markets should be allowed to solve their own problems at their "natural rate" (Palley, 2004: npn).

Neoliberalism's pro-market and anti-labour policies were first implemented by the United States-backed Pinochet dictatorship in Chile (1975). The monetarist economic principles of the above-mentioned Chicago School guided the process. At this time, also, many other governments in the Global South resisted initial demands by Northern-dominated financial institutions such as the World Bank and the International Monetary Fund (IMF) to implement "rapid shock therapy" structural adjustment programmes. With the fall of the Soviet Union in 1989, neoliberal shock therapy was extended to Russia and the other Eastern European countries (Marois \& Pradello, 2015:2-3).

The post-World War II state-led strategies of development gave way to market-oriented neoliberal ones, based on the Washington Consensus. The Washington Consensus is a set of ten economic policy prescriptions considered to constitute the "standard" reform package promoted by the World Bank, the International Monetary Fund and the United States Treasury for crisis-wracked third-world countries. The term "Washington Consensus" was coined in 1980 by English economist John Williamson (Boas \& Gans-Morse, 2009: npn). The term is often used synonymously with "liberalism" and "globalisation". The Consensus consists of ideas such as fiscal discipline, reduction in public (state) expenditure, tax reform, market-determined exchange rates, trade liberalisation, an open door to foreign direct investment, privatisation of public service and state-owned enterprises, deregulation and secure private property rights (Marois \& Pradello, 2015:3). According to some theorists, there now exists an "Augmented Washington Consensus" which, in addition to the items listed above, advocates corporate governance, anti-corruption, flexible labour markets, World Trade Organisation agreements, financial codes and standards, "prudent" capital account opening, non-intermediate exchange rate regimes, independent central banks,

to ensure that the free market produces results close to its theoretical potential. It promotes a strong role for the state with respect to the market, which is in many ways different from the ideas associated with neoliberalism (Ptak, 2009:124-125). 
inflation targeting and targeted poverty reduction (Washington Consensus, 2003; Hall, 2011:17).

What is interesting about Michel Foucault's analysis of the situation in the late 1960s, according to economist Brown (in an interview with Schenk, 2015: npn), is that he grasped (as later published in his book Birth of Biopolitics in 1970) neoliberalism as Europe's present and future in the 1970s - before Thatcher and Reagan were elected, and before the Washington Consensus. What is also remarkable is his appreciation of neoliberalism as a form of political reason and governing that reaches from the state to the soul, and not simply an economic policy. It would therefore not be quite correct, according to Brown, to depict neoliberalism as a straightforward by-product of the 1970s economic turmoil and backlash against welfare states led by a revanchist capitalist elite, as some argue from a Marxist point of view. Most Marxists agree that neoliberalism emerged in the 1970s in response to capitalism's falling rate of profit, the shift of global economic gravity to OPEC, Asia and other sites outside the West, and the dilution of class power generated by trade unions, distributive welfare states, large and lazy corporations, and the expectations generated by educated democracies. From this perspective, neoliberalism is simply "capitalism on steroids": a state and IMF consolidation of class power aimed at releasing capital from regulatory and national constraints, and defanging all forms of popular solidarities.

According to Palley (2009), the Thatcher and Reagan regimes can be viewed as inaugurating the formal period of neoliberal economic policy dominance. Their regimes, and the subsequent unfolding of neoliberalism, are characterised by a deregulation of financial markets, privatisation, the weakening of institutions of social protection (social welfare) (Redwood, 1993:41-44), weakening labour unions and labour market protections, a shrinking government, cutting of top tax rates, opening of international goods and capital markets, and the abandonment of full employment goals. Hall (2011:17) is convinced that Thatcher coined a homespun equivalent for the key neoliberal ideas behind the sea-change she was imposing on British society: value for money, managing your own budget, fiscal restraint, the money supply and the virtues of competition.

Neoliberalism clearly has many variants. According to Hall (2011:12), there are critical differences between American, British and European "social market" versions, South-East Asian state-supported growth and Chinese "state capitalism", Russia's oligarchic state approach and the monetarist "experiments" in Latin America. According to him, neoliberalism is clearly not "one thing"; it evolves and diversifies.

\section{Neoliberalism: How it operates}

As mentioned, neoliberalism is a vague and wraithlike "phenomenon". It is difficult to encapsulate it as either a term, or as an ideology, an influence (Rustin, 2016:153, 154), a set of ideas, a philosophy, a policy, a historical phenomenon, a rationality, a political reason, a paradigm, a set of beliefs and/or principles. The vague and evanescent manifestation of neoliberalism also expresses itself in how it operates in practice.

While no economist or educationist would openly admit to being committed to neo-liberalism as an approach to life and the economy, and education in particular, the pervasive influence of neoliberalism in all walks of life is unmistakeable (Rustin, 2016:154). Neoliberalism, according to Ball (2003:223), in the guise of performativity and managerialism, is "ubiquitous, invisible and inescapable". Because of the stealthy manner in which it insinuates itself into the consciousness of people, including that of educators and educationists, it has been referred to as "the stealth revolution" (Shenk, 2015: npn). It has over the last three or four decades seeped into our social and political fabric and consciousness. Although in general terms its operation in our lives is not directly visible, closer examination will reveal some of its more discernible elements in the fields of economy, business, government, our personal lives and, as will be argued below, also in education. According to political 
scientist Wendy Brown (in an interview with Shenk, 2015: npn), neoliberalism has come to "irrigate every crevice of society, circulating from investment banks to schools, from corporations to universities, from public agencies to schools". Neoliberalism, like all views of life/ideologies, has found its way into the lives of schools and universities; it forces these societal relationships to respond (and often to succumb) to the social pressures exerted on them (cf. Rosenzweig, 1994:13).

Neoliberalism favours a particular (education policy) discourse. For a neoliberal approach to life (and education) the economic reality and rationality are more powerful than all others. Such reasoning is potent because of its potential and tendency to combine economic, social, political and educational dimensions for the sake of rational choice as a principle of legitimacy. Individuals therefore become rational choosers as consumers of commodities, among which education (Adams, 2006:8). According to neoliberalism, the social realm works best if run along "pure forms of rationality" such as the "laws" of demand and supply, laws which should be allowed to operate unfettered by interference in the form of control over, for instance, monopoly or profit-making, or by concerns with the environment or social welfare (Welch, 1998:157). In this way, people are made increasingly captive to the argument that life, including education, must be run along business lines in order to be efficient (Welch, 1998:159). Welch (1998:171) goes so far as to aver "that (neoliberalism allows) economics to masquerade as rationality".

Neoliberalism works in a gradual (Sparkes, 2007:523) and stealthy manner towards the colonisation of and even closing down of people's minds and consciousness (Ball, 2003: 226). The creeping and insidious operation of neoliberalism causes people's reflexivity about who they are, what they are doing and what they and their deeds are worth to be internalised in neoliberal terms (Ball, 220). The end result is that people, also academics, become "ultimate docile bodies" who have internalised the precepts of neoliberalism (Sparkes, 2007:532).

The above description of neoliberalism and how it works has to be qualified with a remark about its different nuances. Neoliberalism as an ideology is contradictory; it is no single, integrated "monolithic" frame of mind. It sutures together a number of (contradictory) lines of argument. One of its contradictions, according to Hall (2011:18), was Premier Margaret Thatcher's approach of a free market combined with an unexpectedly strong role for the state. Despite this, Hall (2011:27) concludes: "In ambition, depth, degree of break with the past, variety of sites being colonised, impact on common sense (cf. Maistry, 2014:60), and shift in the social architecture, neoliberalism does constitute a hegemonic project." As Foucault (in Maistry, 2014:60) correctly observed, the present is contingent; understanding of how the power that has come to create the present (in the form of neoliberalism) also enables us to better position ourselves to disrupt what looks fixed and unsurpassable. In Bourdieu's terms, neoliberalism has succeeded in colonising the habitus of many people, including those of educators and educationists (Maistry, 2014: 60).

\section{Neoliberalism: Its leading ideas}

The following seems to be the root idea of neoliberalism: Factors of production such as labour and capital get paid what they are worth. This is accomplished through the supply and demand process (or "law")(Palley, 2004: npn) in the context of a free market (cf. Bingham, 2000:517 for a rather cynical view of the market). Free markets will not let valuable factors of production, including labour, go to waste. Neoliberalism emphasises market-led development (Marois \& Pradello, 2015:1). Some critics of neoliberalism refer to its stance about the role of the free market as "market fundamentalism with which no one wishes to be associated" (Boas \& Gans-Morse, 2009: npn).

Neoliberalism is furthermore critical of contemporary geopolitics: structural adjustment policies imposed by the World Bank, the IMF and other international organisations have 
forced the developing world to set market forces free (Hall, 2011:12). "The market" has become a modern, rational, practically-oriented discourse, inscribed in the everyday (Hall, 2011:18). It is in this context that neoliberals assume that human well-being can be advanced: it can be promoted by liberating individual entrepreneurial freedoms and skills within an institutional framework characterised by strong property rights, free markets and free trade (Maistry, 2014:62).

In line with the above, neoliberalism emphasises individual rationality (Marois \& Pradello, 2015:1). In markets, the good is generated by individual activity, not by shared political deliberation and rule (Shenk, 2015: npn). Neoliberalism is grounded in the notion of the "free, possessive individual" with the state seen as tyrannical and oppressive. The welfare state, in particular, is seen as the arch enemy of freedom, because it tends to govern society, dictate to free individuals how to dispose of their private property (through taxes), regulate a free market economy, or interfere with the individual's right to make profits and amass personal wealth. State-led social engineering must never prevail over corporate and private interests. It must never interfere in the "natural" mechanisms of the free market or take as its objective the amelioration of free market capitalism's propensity to create inequality (Hall, 2011:10-110). It is against this orientation that Grayling (2010: 218-220) could say of the British state after Thatcher that "...evidently the state chooses its battles, and nannies where it can - usually too far over the boundary. (...) It is tyranny to force others to behave as one think they should, even if one knows for sure what is in their best interests".

It is clear that neoliberalism sees a special role for the state. Whereas classic liberalism sought to liberate the market from regulations in the hope that a free market without restrictions would bring wealth to more, if not everyone, with the state responsible only for providing a social safety net effect, neoliberalism sees the state as taking an active role in the construction of markets, especially in previously social domains such as education and health. The state is expected to create and preserve an appropriate institutional framework that can guarantee the integrity of money, and the proper functioning of markets (Maistry, 2014:62).

Neoliberalism is further seen as a governing rationality through which everything is "economised": human beings are seen as market actors and nothing but; every field of activity is seen as a market and every entity (whether public or private, whether person, business or state) is governed as a business or a firm. Neoliberalism construes even non-wealth generating spheres such as learning, dating, exercising and even religion (De Botton, 2012:294) in market terms, submits them to market metrics, and governs them with market techniques and practices. In the process, it casts people as human capital responsible for constantly tending to their own present and future value (Shenk, 2015: npn).

As mentioned, neoliberalism is concerned with value. Market actors, from individuals to firms, universities to states, restaurants to magazines, are more often concerned with their own speculatively determined value than with immediate profit. All are tasked with enhancing present and future value through self-investments that in turn will attract investors. Financialised market conduct entails increasing or maintaining one's rank or ratings, whether through blog hits, retweets, Yelp stars, college or university ratings or Moody's bond ratings (Shenk, 2015: npn).

\section{The impact of neoliberalism on education}

Neoliberalism has had a profound impact on state (public) and social (private) life in general. It has, for instance, influenced (and promoted) the rise of the view that neither nation states nor welfare states are appropriately qualified to guarantee the freedom and the rights of individuals to promote their personal interests in the form of profit making, the making of choices in life, competing with other individuals and social groups, indulging in practices associated with achievement and the measurement of success, and in doing so striving 
for greater personal success and a sense of achievement. Neoliberals assume that while education has been expected to work in a market regulated by the state, the state has not always been successful in regulating education (Rustin, 2016:154).

In following the tenets and practices associated with neoliberalism, contemporary society has achieved much in terms of democratisation of society (in the form of political freedom being promoted along with economic freedom), and in terms of increasing prosperity. Neoliberalism has a dark side as well, however. It has, according to its critics, led to an obsession with effectivity, effectiveness and efficiency, with individual freedom and choice, with the profit motive associated with business and enterprise, with competition, achievement, assessment/measurement and rating /ranking, with growing prosperity, democratisation (despite the fact that business principles have been edging out the interests of the demos (the people)(cf. Brown in Shenk, 2015: npn), individualisation, materialism and growing inequality and inequity among individuals and social groups - all of these also in the educational context.

As will emerge more clearly in the second part of this discourse, the purpose of this examination of neoliberalism is to engage critically with it and with its theoretical and pretheoretical foundations, particularly as these seem to impact on the view of education resulting from a neoliberal life- and world view. It is therefore important to move beyond its impact on life in general, on the state or business and to attend to how it has manifested in education in particular. The rest of this section will therefore be devoted to a discussion of how it has influenced contemporary educators' and educationists' views of education.

Neoliberals see education as an instrument for sorting and grading learners (a process seen as "natural" to a class society, according to Marxist analysts)(Rustin, 2016:148). According to them, the neoliberal purpose of education is essentially to provide the workforce needed to sustain the capitalist economy, particularly the training of new administrative elite (Rustin, 2016:149). Education, achievement and opportunities are subject to competition; this draws the attention away from the true purposes of education, as will be argued in the second part of this discourse. Assessment is done for purposes of ranking (of learners as well as schools and universities). Schools are tempted to adopt an enterprise culture (in an effort to replace the culture of dependency associated with the welfare state) (Rustin, 2016:155-156).

Education as a form of acculturation has come to be defined as the acquisition of social and human capital. This process depends on increases in knowledge in the workforce at large. Education has become instrumental to business values. Profit-making operations dominate the world, increasingly also in the world of education (Rustin, 2016:150, 153).

There is a tendency not only to reconstitute schools and universities as corporations and to manage their affairs along business lines (Rustin, 2016:154). Welch (1998:171) concludes that the neoliberal approach to education could be seen as an effort towards "a broader reshaping of the social order". Education should be made more cost-efficient through cost containment measures, neo-vocationalism, the commodification of knowledge, disempowerment and deskilling of teachers, the ability to do more with less, greater responsiveness to market forces, engaging in entrepreneurial activities, through quality improvement based on assessment, ranking and grading, quantification, calculability (numbers and figures) (Ball, 2003:215), consumerism, prediction, the use of non-human technology and opting for technicism. The key elements of the education reform package are embedded in three interrelated policy technologies: the market, managerialism and performativity. When employed together, these technologies offer a politically attractive alternative to the state-centred, public welfare tradition of educational provision (Ball, 2003:216).

Education "reform" of this type is spreading across the world like a "policy epidemic" in 
"diverse and social locations which have very different histories" (Ball, 2003:215; compare the remark above about the different guises in which neoliberalism has appeared across the world). The Organisation for Economic Co-operation and Development (OECD) emphasises "monitoring systems" and the "production of information". These aspects of reform engender what Lyotard (1984:216) referred to as the "terror of performativity". As Foucault (1979:294) averred, the purpose of performativity and the concomitant neoliberal educational reform was to "produce bodies that are docile and capable". It is therefore important to understand that neoliberal precepts only reign supreme at schools and universities whose management echelons have fully bought in on neoliberal principles. As will be indicated below, the South African Government and Departments of Education seem to have bought in fairly extensively to such principles.

The South African Schools Act (1996) and the Higher Education Act (1997) envisage a South African education system that would produce citizens who can effectively participate in a global economy (Adams, 2006:3). Institutional management in schools and universities has been structured in such a way that it ensures the steady improvement of education, particularly higher education, by way of the National Qualifications Framework and the South African Qualifications Authority. The system rests upon a policy of reward and punishment, based on external assessment, the criteria for which have been developed by bureaucrats (Adams, 2006:7). The major managerial mechanisms employed by the South African Ministries for Basic and Higher Education and Training are quality assessment and funding (Adams, 2006:8; also cf. Maistry, 2014:66). According to Adams (2016:8), the logic behind these policies is that education is either entirely afforded by government or jointly funded by government, parents and the private sector. In the process, education is seen as a commodity being paid for, and therefore has to be efficiently and effectively managed to yield optimum results. Managerialism holds that there is nothing distinctive about education; it can be conceptualised and managed like any other service, commodity or business enterprise (Adams, 2006:8).

It is in view of observations such as this that Maistry (2014:58) recently concluded that the official purpose of education according to the South African education authorities is to educate for a more productive economy. In his opinion, post-apartheid education has seen "firm and decisive shifts towards performativity and neoliberal market-driven discourses" (Maistry, 2014:63). The problem has been exacerbated by the current African National Congress Government's tendency to "talk left" (in socialist terms about state enterprises such as ESKOM, the South African Airways and education, for instance), and "walk right" (in other words, allowing the free market to run its course, an independent Reserve Bank and privatisation, for instance). The government and the education authorities' buy-in into neoliberalism can be discerned, Maistry (2014:67) contends, in how public schools are encouraged to levy compulsory school fees (contra the notion of free access to public education). This has resulted, in his opinion, in a two-tiered education system (one - the "free" one - catering for the poor, the other paid for by the wealthy). The South African government is also involved in a Mathematics and Science campaign at the expense of the "softer" sciences. It has also adopted a system of high-stakes testing and strong accountability and audit regimes in education. Maistry's (2014:70-71) aversion to neoliberalism in South Africa is clear: "At every turn, South Africans are fed the doctrine of education for economic growth. (...) The neoliberal mantra is pervasive, repetitive and constantly reified: if the nation is doing well (on average), then its citizens must be doing well even if they are extremely poor". South Africans, he avers, "have been overtaken by greed, nepotism, and desire for personal enrichment by certain members..."

It is clear from the above overview that neoliberalism has been having a strong impact on education. It has, among others, given rise to performativity, high-stakes standardised testing, accountability, audit regimes and managerialism. All of these have intruded into the lives and existence of both teachers and their students. 


\section{Concluding remark}

Neoliberalism is yet another of the "-isms" that reformational educators and educationists have to examine and assess in view of the threats and challenges that it might hold for a Scriptural view of society, the human being and particularly education. This part of the article dealt with the problem of what exactly neoliberalism entails and what its main precepts seem to be. It also attempted to describe its impact on education as such. The second part of the article will be devoted to an analysis of neoliberalism as a "philosophy of education". That will be followed by a transcendental-critical analysis of its theoretical and pre-theoretical assumptions. It is hoped that the discussion of neoliberalism offered in this two-part article will have done justice to neoliberalism as well as to a reformational response to its pedagogical orientation.

\section{List of references}

ADAMS, F. 2006. Managerialism and higher education governance: Implications for South African Universities? South African Journal of Higher Education, 20(1):3-14.

BALL, S J 2003. The teacher's soul and the terror of performativity. Journal of Education Policy, 18(2):215228.

BINGHAM, H. 2000. Money Makers. London: HarperCollins.

BOAS, T \& GANS-MORSE, J. 2009. Neoliberalism: From New Liberal Philosophy to Anti-Liberal Slogan. Studies in Comparative International Development, 44(2)137-161.

DE BOTTON, A. 2012. Religion for atheists. London: Hamish Hamilton.

DOOYEWEERD, H.C. 1923. Roomsch-Katolieke en anti-revolutionaire staatkunde. White Paper: Kuyper Foundation.

FOUCAULT, M. 1979. Discipline and Punish. New York: Vintage Books.

GRAYLING, A.C. 2010. Thinking of answers. London: Bloomsbury.

HALL, S. 2011. The neoliberal revolution. Cultural Studies, 75(6):705-728.

JONES, C., PARKER, M \& TEN BOS, R. 2005. For Business ethics. London \& New York: Routledge.

LYOTARD, J.F. 1984. The Postmodern Condition: A report on knowledge. Volume 10. Manchester: Manchester University Press.

MAISTRY, S. 2014. Education for economic growth: A neoliberal fallacy in South Africa! Alternation, 21(1): 57-75.

MAROIS, T. \& PRADELLO, L. 2005. Polarising development - Introducing Alternatives to Neoliberalism and the Crisis. United Kingdom: Pluto Press.

PALLEY, T.I. 2004. From Keyensianism to Neoliberalism: Shifting paradigms in Economics. Foreign Policy in Focus (FPIF). Retrieved on 3 October 2016 at: fpif.org/from_keyensianism_to_neoliberalism_shifting paradigms_in_economics/

PTAK, R. 2009. Neoliberalism in Germany: Revisiting the Ordoliberal Foundations of the Social Market Economy. In: Mirowski, P \& Phlewe, D (Eds.) The Road from Mont Pélerin: The making of the Neoliberal Thought Collective. Cambridge MA: Harvard University Press. P. 124-125.

REDWOOD, J. 1993. The Global Marketplace: Capitalism and its future. London: Harper Collins.

ROSENZWEIG, R. 1994. The permeable university: Academic life in an age of special interests. Interchange, 25(1):11-17.

RUSTIN, M. 2016. The neoliberal university and its alternatives. Soundings, 63:147-176.

SHENK, T. 2015. (2 Apr.) Booked \#3. What exactly is Neoliberalism? Interview with political scientist Wendy Brown.) Dissent. Retrieved on 3 October 2016 at: https://www.dissentmagazine.org/blog/booked-3-whatexactly-is-neoliberalims-wendy-brown-undoing-the-demos

SPARKES, A.C. 2007. Embodiment, academics, and the audit culture: A story seeking consideration. Qualitative Research, 7(4):521-550.

STIGLITZ, J.E. 2013. The pact with the devil. Beppe Grillo's Friends Interview. Retrieved on 4 October 2016 at: Beppegrillo.it/Eng/2007/01/Stiglitz.html 
WASHINGTON CONSENSUS. 2003. Retrieved on 4 October 2016 at: www.cid.harvard.educ/cidtrade/ issues/washington.html

WELCH, A.R. 1998. The cult of efficiency in education: Comparative reflections on the reality and the rhetoric. Comparative Education, 34(2) 157-175. 